\title{
Marine birds and mammals foraging in the rapidly deglaciating Arctic fjord - numbers, distribution and habitat preferences
}

\author{
Lech Stempniewicz ${ }^{1} \cdot$ Michał Goc $^{1} \cdot$ Dorota Kidawa $^{1}$ • \\ Jacek Urbański ${ }^{2}$ - Magdalena Hadwiczak ${ }^{3}$. \\ Adrian Zwolicki ${ }^{1}$
}

Received: 29 April 2016/Accepted: 6 November 2016/Published online: 19 November 2016

(C) The Author(s) 2016. This article is published with open access at Springerlink.com

\begin{abstract}
Climate-induced glacier retreat is considered in the context of its reducing the seaice contact zone used by marine birds and mammals as important foraging grounds and may cause declines in their numbers. To test this hypothesis, a survey was conducted in diversified habitats of a rapidly deglaciating Arctic fjord in Svalbard. Of the fifteen seabird and four mammal species found, coastal surface-feeders prevailed over benthic-feeders and pelagic pursuit-divers. Deep tidewater glacier bays were used by the most numerous but least heterogeneous foraging community, in contrast to the shallow lagoons of coastlineterminating glaciers and deglaciated shorelines. After the 15 years of glaciers retreat documented in Hornsund, the sea-ice contact zone used by birds and mammals has not declined. On the contrary, the increasing freshwater supply from underwater glacial rivers raising zooplankton up to the surface, thus making it available to seabirds, enhances the attractiveness of tidewater glacier bays. Along with the stage of retreat, the importance of glacier bays as feeding grounds changes. Foraging conditions deteriorate when the glacier terminus reaches the coastline and the glacier bay becomes shallower. However, glacier retreat enlarges the area of littoral habitats accessible to benthophages. Glacier-related habitats situated close to colony are used as alternative/emergency feeding grounds by seabirds that normally forage outside the
\end{abstract}

Electronic supplementary material The online version of this article (doi:10.1007/s10584-016-1853-4) contains supplementary material, which is available to authorized users.

Lech Stempniewicz

biols@univ.gda.pl

1 Department of Vertebrate Ecology and Zoology, Faculty of Biology, University of Gdansk, Wita Stwosza 59, 80-308 Gdańsk, Poland

2 GIS Centre, Faculty of Oceanography and Geography, University of Gdansk, Bażyńskiego 4, 80-952 Gdańsk, Poland

3 Pomeranian Landscape Parks, Poniatowskiego 4a, 76-200 Słupsk, Poland 
fjord. This is especially important during the chick-rearing period and also during bad weather conditions in the open sea. Our study demonstrates that, so far, the abundance and species diversity of seabirds foraging in the rapidly deglaciating Hornsund are both high, suggesting that they benefit from the current intensive glacier melt. However, with further climate change an apparent biodiversity paradox may occur. Here, overall biodiversity will increase but local diversity of pagophilic species will decline. Such nonlinear responses complicate the prediction of future polar ecosystem dynamics.

\section{Introduction}

Prominent effects of climate warming in the Arctic are shrinking of the sea ice range and tidewater glacier retreat (ACIA 2005). These are rapidly diminishing the area of sea: ice contact zone (Marginal Ice Zone [MIZ] in case of sea ice), an important part of the Arctic marine ecosystem. Any reduction in this zone will have detrimental consequences for iceassociated algae, invertebrates, fish and the foraging grounds of pagophilic seabirds and marine mammals (Moore and Huntington 2008; AMAP 2012; Sydeman et al. 2012; Post et al. 2013; Barber et al. 2015). A strong relationship was found between glacial recession and the decline of the Kittlitz's murrelet Brachyramphus brevirostris population in Prince William Sound, Alaska (Kuletz et al. 2003). On the other hand, rapid glacier melting may give rise to new habitats that can be used both as breeding and feeding grounds (Grémillet et al. 2015).

Current information on population sizes of seabirds and marine mammals is insufficient for most Arctic areas (Krafft et al. 2006; Lydersen et al. 2014; Descamps et al. 2016). Studies of the locations and sizes of breeding colonies are given priority over the distribution and quantitative exploitation of feeding grounds. Surprisingly, more attention has so far been given to open sea areas (Hunt 1990; Joiris 2011; Gall et al. 2016); yet assessments of the potential impact of a rapidly changing environment relates primarily to fjord areas and especially glacier bays, a subject that has been attracting increased attention (Apollonio 1973; Węławski and Legeżyńska 1998; Stempniewicz et al. 2007; Węsławski et al. 2009; Arimitsu et al. 2012; Lydersen et al. 2014). Although surveys in remote regions can be logistically challenging, baseline information on the distribution and abundance of Arctic marine birds and mammals is essential to identify population changes, estimate and model their importance in ecosystem food webs, and implementing appropriate conservation and management strategies (Diemer et al. 2011; Laidre et al. 2015).

To address the above shortcomings, marine bird and mammal transect surveys were carried out in Burgerbukta (Hornsund, SW Spitsbergen), a biologically very productive area designated a European Marine Biodiversity Flagship Site (Węsławski et al. 2006). Glacier melting in Hornsund fjord is proceeding rapidly (Błaszczyk et al. 2013; Fig. 1), substantially changing the fjord's topography and the breeding/foraging-habitat used by marine birds and mammals. The objectives of this study were: (1) to establish the species composition and abundance of marine birds and mammals foraging in the study area; (2) to assess their distribution and foraging habitat preferences in the fjord. Specific attention was focused on habitats arisen as a result of glacier recession, such as newly emerged non-glaciated seashores, shallowing glacier bays and different stages of glacier receding. With this knowledge to hand, we were able to evaluate the consequences of climateinduced deglaciation for seabirds and mammals foraging in this rapidly transforming Arctic fjord. 


\section{Study area}

Hornsund is an Arctic fjord characterized by a high productivity and species richness (Węsławski et al. 2006). It hosts one of the largest worldwide concentrations of breeding little auks Alle alle, estimated at 400,000-590,000 breeding pairs (Isaksen 1995; L. Keslinka, Univ. Gdansk, unpubl.). There are also several big colonies of kittiwakes Rissa tridactyla, Brunnich's guillemots Uria lomvia and northern fulmars Fulmarus glacialis (size category: 1000-10,000 breeding pairs), and some key areas for the common eider Somateria mollissima and barnacle geese Branta leucopsis. Arctic tern Sterna paradisea, and long-tailed duck Clangula hyemalis are also common breeders in the fiord. Hornsund is, moreover, an important habitat for polar bears Ursus maritimus migrating between Storfjorden and West-Spitsbergen throughout the year (Norwegian Polar Institute, unpubl. data; Wojczulanis-Jakubas et al. 2008).

We studied marine birds and mammals in Burgerbukta, a large bay $\left(34.4 \mathrm{~km}^{2}\right)$ in the Hornsund fjord, SW Spitsbergen (Fig. 1). Our study area included the whole coastal belt around the bay, which is divided by the Luciapynten mountain into two main parts, Vestre and Austre Burgerbukta, each hosting glaciers in different stages of retreat. The first two glaciers, Pajerlbreen and Muhlbacherbreen, are large tidewater glaciers, calving intensively and receding rapidly, which results in a substantial production of large areas of drifting ice of glacial origin. They have deep glacier bays and a frontal zone some $1.5 \mathrm{~km}$ long. The other two glaciers, Kvalfangarbreen and Wibebreen, have a much shorter sea contact zone $(<0.5 \mathrm{~km})$ running largely along the coastline, shallow glacier bays, and exhibit no or very low calving activity and hence minimal production of drifting ice. There are also several small glaciers situated further inland not in direct contact with fjord waters (Fig. 1, Table S1). The extent and density of floating icebergs and floes in the study area depend on the weather conditions and the intensity of calving activity.

The study area encompassed the whole coastline of the Burgerbukta Bay, including sections of different character with regard to coast and littoral type, so we can assume they were representative where bird distribution is concerned. We divided this area into nine linear sectors. Five sectors (A-E) ran along non-glaciated coastline (NGCL), four of them (G1-G4) were glaciated sectors, situated along glacier fronts, two (G1-G2) belonged to sea-terminating tidewater glaciers (STTG) and two (G3-G4) to coastline-terminating glaciers (CLTG). Sector lengths ranged from $0.52-9.0 \mathrm{~km}$, with a total transect length of $29.52 \mathrm{~km}$ (Fig. 1, Tables S1, S5).

\section{Material and methods}

\subsection{Field methods}

We conducted 10 systematic boat-based surveys following the whole coastline from 13 July to 1 August 2014 and 7 surveys from 12 to 23 July 2015. To estimate numbers and distribution of pelagic seabirds in the study area we carried on 5 transect surveys ( 2 in 2014 and 3 in 2015) crossing the bay (transect length $-4.02 \mathrm{~km}$ ). Two observers, one person recording the observations and one boat pilot conducted the surveys between 11:00 and 18:30, covering the whole transect clockwise. We surveyed from a rubber Bombard dinghy, travelling at about $15 \mathrm{~km} / \mathrm{h}$. The height of the observer was $1.5 \mathrm{~m}$ above water. We used line-transect methods (Tasker et al. 1984) to record species, numbers, group sizes and the behaviour of all birds and 


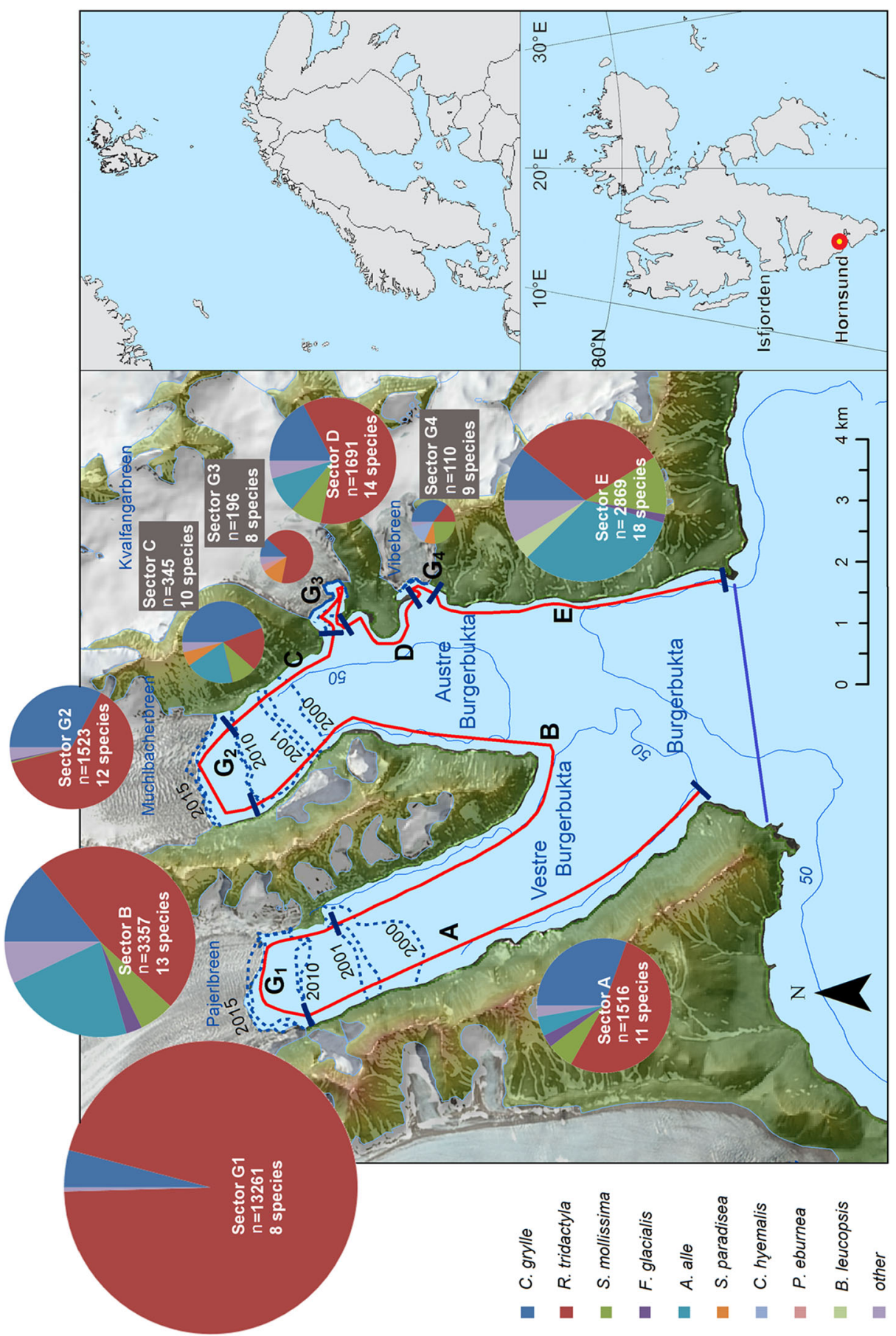


Fig. 1 Study area in Burgerbukta (Hornsund, SW Spitsbergen) with coastal transect (red line) consisting of nine shoreline sectors and one pelagic transect (indigo line) surveyed in July/August 2014-15. Five sectors $(A-E)$ ran along non-glaciated coastline (NGCL), four glaciated sectors $(G 1-G 4)$ were situated along glacier fronts, two $(G 1-G 2)$ belonged to sea-terminating tidewater glaciers (STTG) and two (G3-G4) to coastline-terminating glaciers (CLTG). Pie charts show total number of individuals, number of species and proportions of marine birds and mammals observed in particular sectors ( 2 years combined). Thin blue line denotes $50 \mathrm{~m}$ isobath and dotted lines denote ranges of glacier fronts during 2000-2015

mammals observed. To be consistent with data collected during poor weather conditions, we truncated all our observations to a distance of $150 \mathrm{~m}$ between the boat and the coastline [port side] and another $150 \mathrm{~m}$ on the starboard side of the boat and computed bird densities assuming perfect detection within this $300 \mathrm{~m}$ strip. Each survey covered $8.86 \mathrm{~km}^{2}$ of the transect area. We included all observations of foraging individuals, but excluded birds in flight, resting onshore and on floating ice or bathing within the surveyed area.

Each animal recorded was assigned to a particular transect sector, with the exception of polar bears as they were observed approaching seals in the open water or crossing the fjord. We recorded data using a GPS unit, allowing each observation to be stamped with a time and location. The observers had experience in conducting marine bird surveys in Svalbard or the Baltic Sea and had been trained in bird identification and distance estimation before the surveys. We ceased surveying when the conditions became unsuitable (i.e. winds stronger than Force 3). Meteorological data were obtained from the Meteorological Bulletin issued by the Polish Polar Station, Institute of Geophysics, PAS. Changes in glacier ranges during the period 2000-2015 were obtained by screen digitizing using geometrically corrected Landsat 7 and Landsat 8 satellite images downloaded from http://glovis.usgs.gov. The lengths of glacier fronts and estimates of the deglaciated area in Burgerbukta Bay were calculated with ArcGIS software Release 10.3 (Fig. 1, Tables S2, S3).

Based on foraging strategies, we grouped the seabirds and mammals into three primary foraging guilds: surface feeding [SF], pursuit diving [PD] and benthic feeding [BF], and into two groups with regard to spatial foraging preferences: coastal feeders [CF] and pelagic feeders [PF] (Ainley 1977; Simberloff and Dayan 1991) (Table S5). To estimate the mean total number of seabirds foraging daily in the whole bay we took the sum of (1) the mean number of coastal-feeding seabirds $[\mathrm{CF}]$ and (2) the mean number of pelagic seabirds $[\mathrm{PF}]$ observed within $300 \mathrm{~m}$ of the coastal belt and pelagic transect multiplied by 3.89 , which is the value obtained by dividing the area of Burgerbukta $\left(34.4 \mathrm{~km}^{2}\right)$ by the transect area $\left(8.86 \mathrm{~km}^{2}\right)$.

\subsection{Statistical analysis}

Densities of seabirds foraging in particular sectors and habitats were compared using KruskalWallis rank sum tests; pairwise comparisons were made using the Tukey and Kramer (Nemenyi) tests with the Tukey-Dist approximation for independent samples. Interannual differences in seabird densities were compared using Mann-Whitney tests. Analyses were carried out in $\mathrm{R}$ 3.2.2.

To examine heterogeneity within habitat types, multivariate dispersion indices (MVDISP) were performed and additionally, to describe $\alpha$ diversity between samples/observations, the Shannon diversity index was calculated using natural logarithms (ln). Shannon $\mathrm{H}^{\prime}$ indices and the number of species between habitats were compared using parametric ANOVA with the Welch correction for non-equal variances. 
Similarity between the observations was given by non-metric multidimensional scaling (NMDS). Differences between habitats were examined with one-way ANOSIM (analysis of similarities, with the Monte Carlo permutation test). Similarity percentages analysis (SIMPER) was used to define the contribution of each species to dissimilarities between the habitat types. These analyses were run on log-transformed data $\left[\mathrm{x}^{\prime}=\log (\mathrm{x}+1)\right]$ with Bray-Curtis distances between samples.

Since the length of gradient of dataset measured on the 1th axis of Detrended Correspondence Analysis (DCA) was $>3$, therefore we decided to use unimodal Canonical Correspondence Analysis (CCA) which was used to examine the influence of habitat types on the species composition variability. Because of the length of the gradient in the dataset (DCA, SD >3), Canonical Correspondence Analysis (CCA) was used to examine the influence of habitat types on the species composition variability. To test for the significance of this factor, the Monte Carlo test was performed (with 499 permutations). The efficiency (\%) of the tested environmental variable in explaining any non-random variability in the dataset was calculated by dividing the percentage variability explained by a given environmental factor by that explained by the first four axes of DCA (carried out at the beginning of the analysis). All ordination techniques were based on log-transformed data $\left[\mathrm{x}^{\prime}=\log (\mathrm{x}+1)\right]$. For multiple comparisons we used Holm's correction to control for family-wise type I errors.

To explore significant positive and negative preferences of individual animal species to habitat type, a t-value biplot (with Van Dobben circles) which approximates the t-values of the regression coefficients of a weighted multiple regression, was generated. Where $T>2$ represents statistically significant $(p<0.05)$ positive preference $(+)$ and similarly $T<-2$ represent negative preference (-).

Variation partitioning (VP) based on two unimodal ordination technique (CCA) was applied to explore whether the variability between observations explained by habitat type was similar in both study years. In this procedure we used one set of response variables (birds and mammal species compositions) and two sets of predictors: (1) with the three-stage habitat factor (NGCL, STTG and CLTG) and (2) with the two-stage study year factor (2014 and 2015).

The results were processed using the STATISTICA 12 package for comparison between groups. The ordination techniques (NMDS, DCA, CCA) and t-values were performed in Canoco 5.03. Analysis of Similarity (SIMPER, ANOSIM) and Multivariate Dispersion (MVDISP) analyses were calculated in Primer 6.1.5.

\section{Results}

\subsection{Species composition and numbers}

In the study area we recorded a total of 10,568 individual birds of 15 species during 10 surveys in 2014 and 18,705 during 7 surveys in 2015 (mean 1056.8 and 2672.1 per survey, respectively). Mean density of the three most numerous pelagic seabirds, i.e. fulmar, little auk and Brunnich's guillemot, was similar in the pelagic transect crossing the bay and in the coastal sectors (Tukey \& Kramer post hoc test, $p>0.05$ ), which allowed us assuming their uniform distribution in Burgerbukta. On average at least 1200 of seabirds (in 2014) and 3500 (in 2015) were foraging daily in Burgerbukta. The most abundant bird species observed were blacklegged kittiwake and black guillemot Cepphus grylle followed by little auk and common eider. The least numerous were king eider Somateria spectabilis and ivory gull Pagophila eburnea, 
both species of special conservation concern. During 17 surveys we recorded four species of marine mammals, including sixteen ringed seals Pusa hispida, five bearded seals Erignathus barbatus, twenty-three belugas Delphinapterus leucas and two polar bears (Table S5).

Surface feeders [SF] constituted $65.0 \%$ of the estimated total number of seabirds foraging daily in Burgerbukta Bay, followed by pursuit divers [PD] (25.4\%) and benthic feeders [BF] $(9.6 \%)$. As far as spatial foraging selection is concerned, the proportion of coastal feeders [CF] was $71.4 \%$, far outnumbering pelagic feeders [PF] (28.6\%) (Table S5).

\subsection{Distribution, habitat selection and species richness}

The great majority of kittiwakes and ivory gulls, as well as ringed and bearded seals were observed in glacier bays. However, over $90 \%$ of the little auks, Brunnich's guillemots and common eiders, as well as the majority of glaucous gulls, fulmars and Arctic terns, were observed foraging in non-glaciated sectors (Table S5).

Densities of kittiwakes foraging in tidewater glaciers $\mathrm{G}_{1}-\mathrm{G}_{2}$, coastline terminating glaciers $\mathrm{G}_{3}-\mathrm{G}_{4}$ and in non-glaciated sectors differed substantially (K-W test, $\chi^{2}=70.69$, df $=2$, $p<0.0001$; two years combined). They were observed in frontal zones of tidewater glaciers in considerably higher densities compared to coastline terminating glaciers (Tukey and Kramer post hoc test, $p<0.001$ ) and non-glaciated sectors (Tukey and Kramer post hoc test, $p<0.0001)$. Shallow bays of coastline terminating glaciers $\left(\mathrm{G}_{3}-\mathrm{G}_{4}\right)$ did not differ significantly in the density of foraging kittiwakes from non-glaciated sectors (A-E; Tukey and Kramer post hoc test, $p=0.22$ ).

The density of foraging black guillemots also differed considerably between tidewater glaciers, coastline terminating glaciers and non-glaciated sectors $\left(\mathrm{K}-\mathrm{W}\right.$ test, $\chi^{2}=30.95$, $\mathrm{df}=2, p<0.0001)$. The highest densities were observed in the bays of tidewater glaciers $\mathrm{G}_{1}-\mathrm{G}_{2}$ which outnumbered coastline terminating glaciers $\left(\mathrm{G}_{3}-\mathrm{G}_{4}\right.$; Tukey \& Kramer post hoc test, $p<0.0001$ ) and the remaining non-glaciated sectors (A-E; Tukey \& Kramer post hoc test, $p<0.0001)$. Coastline-terminating glaciers $\left(\mathrm{G}_{3}-\mathrm{G}_{4}\right)$ did not differ significantly from non-glaciated sectors (A-E) in the density of foraging black guillemots (Tukey \& Kramer post hoc test, $p=0.58$ ).

Common eiders occurred in substantially different densities between the habitats (K-W test, $\left.\chi^{2}=42.50, \mathrm{df}=2, p<0.0001\right)$. They occurred in a higher density in non-glaciated sectors (D and $\mathrm{E}$ - most occupied) than in front of tidewater glaciers $\left(\mathrm{G}_{1}-\mathrm{G}_{2}\right.$; Tukey \& Kramer post hoc test, $p<0.0001)$, as well as in front of coastline-terminating glaciers $\left(\mathrm{G}_{3}-\mathrm{G}_{4}\right.$; Tukey \& Kramer post hoc test, $p=0.001$; K-W test, $\left.\chi^{2}=42.50, \mathrm{df}=2, p<0.0001\right)$. Also, little auks were observed foraging non-randomly between the habitats $\left(\mathrm{K}-\mathrm{W}\right.$ test, $\chi^{2}=31.40$, df $=2$, $p<0.0001)$. Their density was higher in non-glaciated sectors than in front of tidewater and coastline-terminating glaciers (Tukey \& Kramer post hoc test, $p<0.005$ ). The density of both species did not differ between the two types of glaciers (Tukey \& Kramer post hoc test, $p=0.16)$.

Using analysis of similarity (ANOSIM one-way analysis, global test, $R=0.37, p=0.001$, all pairwise comparisons $p=0.001$ ) we confirmed the distinction of the three types of habitats occupied by marine birds and mammals in Burgerbukta. The non-metric multidimensional scaling (NMDS) plot based on the species composition similarity shows that these habitat groups are clearly separated. Samples within the sea-terminating tidewater glaciers represented the smallest differentiation (MVDISP $=0.36$ ) compared with coastline-terminating glaciers $($ MVDISP $=1.33)$ and non-glaciated coastline $($ MVDISP $=1.06)($ Fig. 2a). 

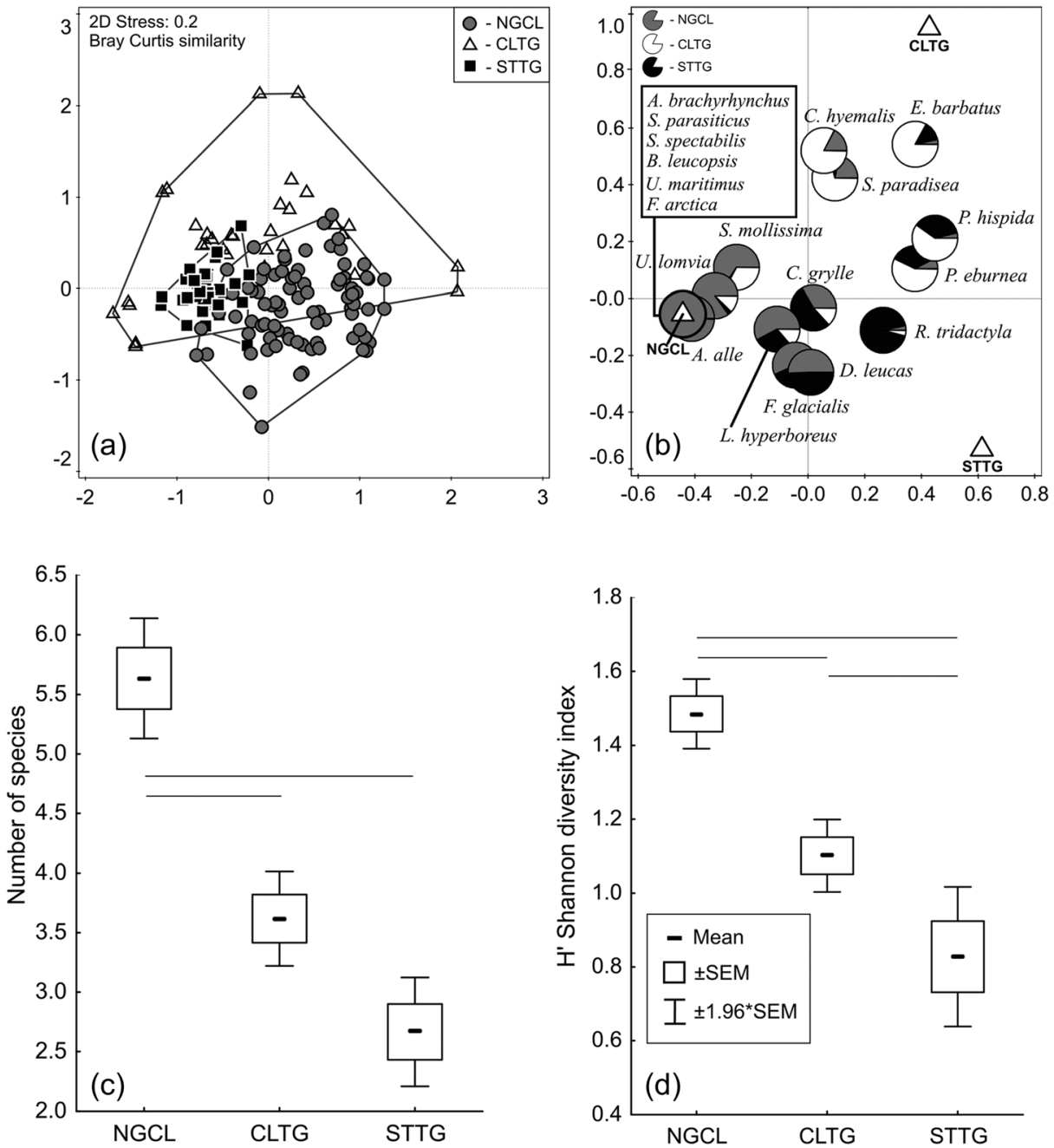

Fig. 2 Comparison of the three distinguished habitat types (NGCL: non-glaciated coastline, STTG: seaterminating tidewater glaciers, $C L T G$ : coastline-terminating glaciers). a: NMDS ordination diagram based on similarity of species composition within the three habitat types, plotted with envelopes; b: CCA ordination diagram with pie charts describing species participation in density within the three habitat types. Triangles present ordination of the environmental factor; c: number of marine bird and mammal species; $\mathbf{d}$ : Shannon diversity index. Significant differences (post-hoc, $p<0.01$ ) between the habitats are indicated by horizontal lines

Similarity Percentage Analysis (SIMPER) performed pairwise revealed the evident differentiation of coastline habitats. The highest average dissimilarity (67.96) was found between the NGCL vs. CLTG habitats, and only slightly lower differences were found between STTG vs. CLTG (60.41) and NGCL vs. STTG (60.00) habitats. For all three comparisons, the highest dissimilarity between the groups was caused by kittiwake followed by black guillemot dominating in STTG. Common eider, achieving its highest average density in NGCL, also made an important contribution to the dissimilarity between the habitats. Non-glaciated coastline was characterized by the highest abundance of little auk and CLTG was distinguished by the highest abundance of Arctic tern (Table 1). Based on the T-value biplot technique, 
Table 1 SIMPER analysis of species composition in the three distinguished habitats

\begin{tabular}{llllllllll}
\hline & Species & AA & HP & AA & HP & AD & Contribution [\%] & Total AD \\
\hline NGCL vs. CLTG & & NGC & & CLTG & & & \\
& Rissa tridactyla & 1.22 & {$[-]$} & 1.95 & {$[+]$} & 11.65 & 17.14 & 67.96 \\
& Cepphus grylle & 2.55 & $n s$ & 1.97 & $n s$ & 10.17 & 14.96 & \\
& Somateria mollissima & 1.46 & $n s$ & 0.84 & $n s$ & 9.68 & 14.24 & \\
& Sterna paradisea & 0.42 & {$[-]$} & 1.35 & {$[+]$} & 8.10 & 11.92 & \\
NGCL vs. STTG & & NGCL & STTG & & & & \\
& Rissa tridactyla & 1.22 & {$[-]$} & 5.18 & {$[+]$} & 20.62 & 34.37 & \\
& Cepphus grylle & 2.55 & {$[-]$} & 3.50 & {$[+]$} & 6.91 & 11.52 & \\
& Somateria mollissima & 1.46 & {$[+]$} & 0.14 & {$[-]$} & 6.65 & 11.08 & \\
& Alle alle & 1.03 & {$[+]$} & 0.08 & {$[-]$} & 4.61 & 7.69 & \\
STTG vs. CLTG & & STTG & CLTG & & & \\
& Rissa tridactyla & 5.18 & {$[+]$} & 1.95 & {$[-]$} & 19.33 & 32.00 & \\
& Cepphus grylle & 3.50 & $n s$ & 1.97 & $n s$ & 11.41 & 18.88 & \\
& Sterna paradisea & 0.21 & {$[-]$} & 1.35 & {$[+]$} & 7.00 & 11.59 & \\
& Somateria mollissima & 0.14 & {$[-]$} & 0.84 & {$[+]$} & 4.76 & 7.88 & \\
\hline
\end{tabular}

$N G C L$ - non-glaciated coastline, CLTG - coastline land-terminating glaciers, STTG - sea-terminating tidewater glaciers. $A A$ - average abundance $\left(\mathrm{N} / \mathrm{km}^{2}\right)$ based on transformed data, $H P$ - habitat preferences based on T-value biplot: [+] significant positive $(p<0.05, T>2),[-]$ significant negative $(T<-2), n s$ - non-significant; $\quad A D-$ average dissimilarity. Species selection based on four most contributing species in dissimilarity at cumulative contribution cut-off level $\geq 60 \%$

kittiwake selected both glaciated habitats (CLTG and STTG), with the highest average abundance in STTG. A significant selection for NGCL was found only for little auk and common eider (Table 1).

The number of species and the $\alpha$ diversity index (Shannon $\mathrm{H}^{\prime}$; seabirds and mammals and two years combined) differed significantly between the three habitat types, achieving the highest values for non-glaciated coastline sectors (ANOVA Welch test, $\mathrm{F}=37.33$, $\mathrm{df}=2$, $p<0.001$ and $\mathrm{F}=25.69, \mathrm{df}=2, p<0.001$ respectively, with significant differences in all pairs (post-hoc Tukey, $p<0.01$ ) except the number of species in the CLTG vs. STTG comparison). Sea-terminating tidewater glacier bays were characterized by large numbers of foraging birds and mammals, principally kittiwake, and by a low species richness (Fig. 2c, d). The similarity of the proportional occurrence (measured as density) of species in the three habitats was subjected to canonical-correspondence analysis (CCA), which confirmed the relationship of particular species with the habitat types. Over $50 \%$ of kittiwakes and black guillemots occurred in STTG. Long-tailed ducks, Arctic terns and ivory gulls, as well as both seal species, selected CLTG. However, little auks, Brunnich's guillemots and common eiders were associated with NGCL. Northern fulmar and beluga used both NGCL and STTG in similar ways. The habitat factor significantly explained $13.4 \%$ of the total variation in the species composition of birds and mammals (CCA, Monte Carlo permutation test, pseudo-F $=12.5 \mathrm{df}=2 ; p=0.002$; Fig. 2b).

\subsection{Temporal variability}

We found considerable interannual differences in seabird densities observed foraging in the study area. The most striking difference concerned kittiwakes $(\mathrm{M}-\mathrm{W}$ test, $\mathrm{W}=3475$, 
$p=0.0059)$ and little auks (M-W test, $\mathrm{W}=1837, p<0.0001)$ and, to a lesser extent, also black guillemots $(\mathrm{M}-\mathrm{W}$ test, $\mathrm{W}=2103, p=0.0131)$. All these species were observed in higher numbers in 2015 than in 2014 (Table S5). However, these interannual differences had no effect on either distribution or habitat choice of marine birds and mammals, which was shown by the results of Variation Partitioning (shared variation between habitat and year factors $=0$ ). The number and density of kittiwakes and black guillemots observed during particular surveys in the two study years were significantly correlated (Spearman $r_{s}=0.79, p=0.0016$ ).

\section{Discussion}

\subsection{Foraging community structure and habitat preferences}

The species composition and proportions of seabirds foraging in the study area reflected partly the size of local breeding populations as well as their spatial and habitat foraging preferences. The most abundant was the surface-feeding black-legged kittiwake (c. 50,000 birds breeding in Hornsund in 4 colonies), which normally forages away from the fjord and uses glacial bays as important alternative feeding grounds (unpubl. pers. GPS telemetry data). Much less abundant were the benthic-feeding black guillemot and common eider, both with an unknown but definitely smaller and scattered breeding population in the fjord. Being short-distance foragers (Cairns 1987), they do not leave the fjord to feed. The pursuit-diving little auk, with a huge local breeding population (c. half million pairs) exploits the outer feeding grounds (Jakubas et al. 2012, 2013, 2014); only a small number of them forage in the fjord, presumably during bad weather. The least numerous were king eider and ivory gull, species of special conservation concern. Coastal feeders exploiting primarily the tidewater glacier bays predominated over the largely pelagial feeders, which generally showed no fixed spatial aggregations, but some of them, e.g. northern fulmars, were observed using intensively changing prey hot spots associated with "brown zones". "Brown zone" is an area in front of tidewater glaciers that is ice-free due to currents and muddy due to suspended sediments. This zone is considered as foraging hotspot for seabirds, seals and white whales (Lydersen et al. 2014). This term and description was used for the first time by Hartley and Fisher (1936). However, only relatively small part of the "brown zone" is trophically attractive including areas where glacier river discharges and also the border of the fresh and marine waters. Due to wave and wind activity the "brown zone" is often broken into separate long stripes moving on the surface of the water far away from the glacier bay and we observed numerous fulmars foraging along them.

Four marine mammal species were represented by bearded seal, beluga whale, ringed seal and polar bear. Pinnipeds and polar bears, which rely on the former as the main item in their diet, are strongly associated with sea ice as a breeding, hauling and hunting habitat. The rapid sea ice decline and deglaciation of recent decades in the Arctic is commonly thought to be having dramatic consequences for their population numbers, distribution and feeding habits (Moore and Huntington 2008; Kovacs et al. 2011; Gilg et al. 2012; Prop et al. 2015; Descamps et al. 2016). Also, several seabird species, including kittiwake, black guillemot and ivory gull, are definitely ice-associated and hence seriously threatened by ice-cover shrinking (Bradstreet and Cross 1982; Mehlum and Gabrielsen 1993; Gilchrist and Mallory 2005; Descamps et al. 2016). Even seabirds which are not directly related with sea ice use MIZ as important foraging grounds. Using GPS loggers we have documented that little auks breeding in Magdalenefjorden (NW Spitsbergen) can fly over $100 \mathrm{~km}$ to MIZ to feed there on ice 
associated crustaceans (Jakubas et al. 2012). All species of pagophilic marine birds and mammals are considered sensitive indicators of climate change (Hoegh-Guldberg and Bruno 2010; Post et al. 2013).

Comparison of our results with those obtained in other Arctic fjords shows that the abundance of seabirds foraging in Burgerbukta is high. Diemer et al. (2011), using the same census method and transect width $(300 \mathrm{~m})$ in Cumberland Sound fjords (Baffin Island, Nunavut, Canada), recorded 959 birds from nine species during a $173 \mathrm{~km}$ effort, i.e. 5.5 ind. $\mathrm{km}^{-1}$. Schoen et al. (2013) observed a total of 1496 seabirds of 24 species on $225 \mathrm{~km}$ of the transects surveyed in June in Yakutat Bay, Alaska, yielding 6.65 ind. $\mathrm{km}^{-1}$. In our study area we recorded in total 562 seabirds from 9 species (15 species in whole Burgerbukta) on $20.1 \mathrm{~km}$ surveyed during two years, which gives 27.9 ind. $\mathrm{km}^{-1}$ surveyed. However, we have to treat these comparisons cautiously as both, Diemer et al. (2011) and Schoen et al. (2013), used transect method with prevailing pelagic parts of the vast study areas and we based on much shorter pelagic transect conducted at the entrance to considerably smaller Burgerbukta. The total number of 45 mammal sightings in Burgerbukta during the 17 surveys in our study is much lower than the 101 sightings in Cumberland Sound; in the latter site however, harp seals Pagophilus groenlandicus alone (73 ind.) constituted the great majority of observations. In both areas, the marine mammalian fauna was represented by four species.

Our study took place during the nestling period, i.e. during the time of heightened energy demands and limited foraging range of parent birds owing to the necessity of regularly returning to the colony to feed chicks. In 2015 (but not in 2014), when much higher numbers of seabirds foraged in the fjord, we found that the number of little auks foraging in Burgerbukta clearly rose during the study period as chick energy demands increased. The number of kittiwakes, however, declined in the same period. These two species differ largely as to the foraging methods/preferences and type and energy cost of flight and may respond in different ways to wind conditions at open-sea foraging grounds. Little auks avoid areas with turbid water and/or with high abundance of small-sized copepods (e.g. Calanus finmarchicus) making selection of their staple prey (C. glacialis) difficult (Stempniewicz et al. 2013; Vogedes et al. 2014). Kittiwakes feeding efficiently on the surface of the water, including "brown zones", seem not to be affected by this problem. No distinct temporal trends in numbers of black guillemots were observed: these forage within a short distance $(<$ $15 \mathrm{~km}$ ) of the colony and exhibit strong foraging site fidelity (Cairns 1987). The numbers and densities of kittiwakes and black guillemots observed on particular days of the two study years were significantly correlated, suggesting that changing foraging conditions affected these two seabird species in a similar way. Indeed, both these species are strongly associated with the ice density and distribution in the fjord, which depend on the weather conditions (wind power and direction, tidal cycle, precipitation) and glacier calving activity on a particular day.

The considerable interannual differences found in the number of kittiwakes and little auks foraging in the fjord could be related to the wind characteristics in the outer Hornsund area during the study period in both years. July 2015 was an exceptionally windy month in the history of the long-term (starting from 1978) meteorological observations of the Polish Polar Station. Wind parameters, and especially the maximum values as well as the number of days with strong wind $(\geq 10 \mathrm{~m} / \mathrm{s})$, were considerably higher in July 2015 compared to July 2014 (Table S4). Consequently, the total seabird number observed foraging daily in Burgerbukta was c. 
threefold higher in 2015 (fourfold in the case of kittiwake and c. 30 times higher in the case of little auk). However, in absolute values this dramatic change was caused almost exclusively by the increase in kittiwake numbers in 2015 , which is supported by GPS-tracked birds in both years. In the more windy July 2015, nearly half (49\%) of the kittiwakes foraged in the fjord compared with 14\% in 2014 (Tables S4, S5; own unpubl. data). Such an opportunity for emergency feeding close to the colony when weather conditions beyond the fjord are bad may increase the breeding success of birds (Jakubas et al. 2013, 2014; Kidawa et al. 2015; Hilde et al. 2016) and buffer the adverse consequences of climatic and oceanographic changes (Grémillet et al. 2012, 2015).

\subsection{Consequences of glacier retreat for seabirds and mammals}

Attractiveness of the glacier fronts to seabirds and marine mammals has been well known for a long time (Hartley and Fisher 1936; Węsławski and Legeżyńska 1998; Lydersen et al. 2014). However, high concentrations of food at tidewater glacier bays is explained in different ways. Apollonio (1973) relates this to enhanced productivity through provision of nutrients from sub-glacial waters. Another explanation is that the freshwater entering the sea at the bottom of glacier causes an osmotic shock to the invertebrates and fish that subsequently are raised to the surface with the upwelling current, making them easily available to surface feeding birds (Hartley and Fisher 1936; Węsławski and Legeżyńska 1998). Recently, Lydersen et al. (2014) regarded glacier rivers discharge responsible for formation of these foraging hot spots. Whatever physical features creating these specific foraging sites, climate warming and proceeding glacial melting is thought to reduce these important foraging areas (Kohler et al. 2007). As a consequence this may cause a significant decrease in numbers of pagophilic species (Gilchrist and Mallory 2005; Moore and Huntington 2008; Cottier et al. 2010; Lydersen et al. 2014; Descamps et al. 2016).

However, during 15 years (2000-2015) of glacier retreat in Hornsund fjord, the area of the sea-ice contact zone has not shrunk. At the same time, the area uncovered by receding tidewater glaciers in Burgerbukta amounted to $7.1 \mathrm{~km}^{2}$. In addition, the length of receding tidewater glacier fronts, determined largely by fjord width, did not change significantly, and even increased by c. $2200 \mathrm{~m}$ (Fig. 1, Tables S2, S3). In contrast, the high rate of glacier retreat is correlated with increasing calving and melting (van der Veen 2004), which results in the release of large volumes of freshwater by glacier rivers and enlarges the area of littoral habitats accessible to benthophagous animals. Moreover, the proportion of fjord water area filled with drifting glacier-ice is considerably extended, favouring ice-associated prey taxa (amphipods, euphausiids and polar cod Boreogadus saida), which constitute an important part of the diet of many birds and mammals (Bradstreet and Cross 1982; Mehlum and Gabrielsen 1993). In our study area, the tidewater glacier bays supported a much higher number of birds and mammals but a lower species diversity compared to other, non-glaciated parts of the study area.

Attractive glacier-related habitats situated close to colony are used by seabirds that normally forage outside the fjord (Kotzerka et al. 2010; Jakubas et al. 2012) as supplementary/ contingency feeding grounds. For kittiwakes, these areas are at least temporarily of great significance. Large numbers of them were observed in tidewater glacier bays - as many as 
10,000 individuals foraging simultaneously along the c. $300 \mathrm{~m}$ frontline of Hornbreen (personal obs.). This is especially important for chick-rearing seabirds when the weather out at sea is bad.

Climate controls the advance/retreat cycle of calving glaciers during most of the cycle, but there are climate insensitive periods as well. Depending on the type and stage of the cycle, glaciers behave differently. Tidewater glaciers accelerate toward the terminus, which enhances their response to climate changes, whereas land-terminating glaciers slow down: this demonstrates the response of glaciers to climate. The calving rate is largely controlled by the depth of the water and the glacier velocity at the calving front. This is observed, for example, in the Svalbard Archipelago (van der Veen 2004).

Depending on the retreat stage, glacier bays have a different importance for marine birds and mammals. The most attractive foraging grounds are formed in tidewater glacier bays, where glacier rivers discharge deep underwater, from which zooplankton is raised to the surface. This is the case of Pajerlbreen, where two large under-glacier rivers flow out deep and come to the surface close to the glacier forehead. They form strong freshwater plumes, expelling substantial quantities of zooplankton drawn in from a large area of deeper water up to the surface, thus making them easily available to surface-feeding seabirds (Lydersen et al. 2014). Much smaller numbers of seabirds were observed in the vicinity of Muhlbacherbreen, another tidewater glacier in our study area. Its glacier river, however, reaches the fjord superficially out of the glacier front and does not create any foraging hot spot effect. Coastline-terminating glaciers (Kvalfangarbreen and Wibebreen in our study) appear to be trophically the least attractive. Their glacier rivers inevitably disembogue superficially into shallow bays and are of less importance as foraging areas.

More advanced stages of glacier retreat may positively influence seabirds by creating new, diversified foraging habitats used by a higher number of seabird species. Coastline-terminating glacier bays and parts of the shore newly uncovered by glaciers receding farther inland promote the heterogeneity of the seabird foraging community. The intensive summer melting of such inland glaciers creates a network of rivulets bringing freshwater to the sea, thus enhancing the diversity of feeding sites. Such a type of coast (sector E in our study), with three small glaciers situated c. $1 \mathrm{~km}$ from the seashore (Krusebreen, Urnebreen, Lorchbreen), was characterized by the highest species richness (Table S1, Fig. 1).

There are many uncertainties arising from the effect of climate change on icedependent animals and the Arctic food web as a whole (Moore and Huntington 2008). Marine bird and mammal sensitivity to the loss of sea ice habitat will depend partially on current population sizes and distributions, which will need to be monitored in order to identify species at risk and to employ appropriate conservation strategies (Gaston et al. 2005; Laidre et al. 2008, 2015; Moe et al. 2009; Hoegh-Guldberg and Bruno 2010; Lydersen et al. 2014). Widely recorded sea ice shrinking and rapid glacier retreating may have different ecological consequences on coastal trophic seabird and mammal foraging communities. However, reports on negative consequences predominate in the case of both seabirds (e.g. Kittlitz's murrelet and ivory gull; Kuletz et al. 2003) and seals and polar bear (Kovacs et al. 2011; Gilg et al. 2012; Post et al. 2013; Prop et al. 2015; Descamps et al. 2016). Our study demonstrates that the densities and species diversity of seabirds foraging in Hornsund are high compared with other studied Arctic fjords, suggesting that so far, they are benefitting from the current intensive glacier melting. However, with further climate change an apparent biodiversity paradox may occur. Here, 
overall biodiversity will increase but local diversity of pagophilic species will decline. Such nonlinear responses complicate any predictions of future polar ecosystem dynamics.

Acknowledgements We wish to thank our colleagues Mateusz Barcikowski and Lech Iliszko for their contributions to the surveys and invaluable help during the fieldwork. This work was funded by a grant from the Polish National Centre for Research and Development - PNRF (GLAERE, POL-NOR/199377/91/2014) and conducted under permission of the Governor of Svalbard.

Open Access This article is distributed under the terms of the Creative Commons Attribution 4.0 International License (http://creativecommons.org/licenses/by/4.0/), which permits unrestricted use, distribution, and reproduction in any medium, provided you give appropriate credit to the original author(s) and the source, provide a link to the Creative Commons license, and indicate if changes were made.

\section{References}

ACIA (2005) Arctic climate impact assessment. Cambridge University Press, Cambridge, 1042 pp

Ainley DG (1977) Feeding methods in seabirds: a comparison of polar and tropical nesting communities in the eastern Pacific Ocean. In: Llano GA (ed) Adaptations within Antarctic ecosystems. Smithsonian Institution, Washington, pp. 669-685

AMAP (2012) Arctic climate issues 2011: changes in Arctic snow, water, ice and permafrost. SWIPA 2011 Overview report. Arctic Monitoring and Assessment Programme (AMAP), Oslo.

Apollonio S (1973) Glaciers and nutrients in Arctic seas. Science 180:491-493

Arimitsu ML, Piatt JF, Madison EN, Conaway JS, Hillgruber N (2012) Oceanographic gradients and seabird prey community dynamics in glacial fjords. Fish Oceanogr 21:148-169

Barber DG, Hop H, Mundy CJ, Else B, Dmitrenko IA, Tremblay J-E, Ehn JK, Assmy P, Daase M, Candlish LM, Rysgaard S (2015) Selected physical, biological and biogeochemical implications of a rapidly changing Arctic marginal ice zone. Progr Oceanogr 139:122-150. doi:10.1016/j.pocean.2015.09.003

Błaszczyk M, Jania JA, Kolondra L (2013) Fluctuations of tidewater glaciers in Hornsund Fiord (Southern Svalbard) since the beginning of the twentieth century. Pol Polar Res 34:325-350

Bradstreet MSW, Cross WE (1982) Trophic relationships at high Arctic ice edges. Arctic 35:1-12

Cairns DK (1987) The ecology and energetics of chick provisioning by black guillemots. Condor 89:627-635

Cottier FR, Nilsen F, Skogseth R, Tverberg V, Svendsen H, Skarðhamar J (2010) Arctic fjords: a review of the oceanographic environment and dominant physical processes. In: Howe JA, Austen WEN, Forwick M, Paetzel M (eds) Fjords: depositional systems and archives. Geol Soc, vol 344. Spec Publ, London, pp. 35-50

Descamps S, Aars J, Fuglei E, Kovacs KM, Lydersen C, Pavlova O, Pedersen ÅØ, Ravolainen V, Strøm H (2016) Climate change impacts on wildlife in a high Arctic archipelago - Svalbard, Norway. Glob Change Biol, in press. doi: $10.1111 / \mathrm{gcb} .13381$

Diemer KM, Conroy MJ, Ferguson SH, Hauser DDW, Grgicak-Mannion A, Fisk AT (2011) Marine mammal and seabird summer distribution and abundance in the fjords of Northeast Cumberland sound of Baffin Island, Nunavut, Canada. Polar Biol 34:41-48

Gall AE, Morgan TC, Day RH, Kuletz KJ (2016) Ecological shift from piscivorous to planktivorous seabirds in the Chukchi Sea, 1975-2012. Polar Biol. doi:10.1007/s00300-016-1924-z (in press)

Gaston AJ, Gilchrist HG, Hipfner J (2005) Climate change, ice conditions and reproduction in an Arctic nesting marine bird: Brunnich's guillemot (Uria lomvia L.). J Anim Ecol 74:832-841

Gilchrist HG, Mallory ML (2005) Declines in abundance and distribution of the ivory gull (Pagophila eburnea) in Arctic Canada. Biol Conserv 121:303-309. doi:10.1016/j.biocon.2004.04.021

Gilg O, Kovacs KM, Aars J, Fort J, Gauthier G, Grémillet D, Ims RA, Meltofte H, Moreau J, Post E, Schmidt NM, Yannic G, Bollache L (2012) Climate change and the ecology and evolution of Arctic vertebrates. Ann N Y Acad Sci 1249:166-190

Grémillet D, Welcker J, Karnovsky NJ, Walkusz W, Hall ME, Fort J, Brown ZW, Speakman JR, Harding AMA (2012) Little auks buffer the impact of current Arctic climate change. Mar Ecol Prog Ser 454:197-206

Grémillet D, Fort J, Amélineau F, Zakharova E, Le Bot T, Sala E, Gavrilo M (2015) Arctic warming: nonlinear impacts of sea-ice and glacier melt on seabird foraging. Glob Change Biol 21:1116-1123. doi:10.1111/gcb.12811

Hartley CH, Fisher J (1936) The marine foods of birds in an inland fjord region in West Spitsbergen. Part 2. Birds J Anim Ecol 5:370-389 
Hilde CH, Pélabon C, Guéry L, Gabrielsen GW, Descamps S (2016) Mind the wind: microclimate effects on incubation effort of an arctic seabird. Ecol and Evol, in press. doi:10.1002/ece3.1988

Hoegh-Guldberg O, Bruno JF (2010) The impact of climate change on the world's marine ecosystems. Science 328:1523-1528

Hunt GL Jr (1990) The pelagic distribution of marine birds in a heterogeneous environment. Polar Res 8:43-54

Isaksen K (1995) The breeding population of little auk (Alle alle) in colonies in Hornsund and northwestern Spitsbergen. In: Isaksen K, Bakken V (eds) Seabird population in the northern Barents Sea, Meddelelser No, vol 135. Norwegian Polar Institute, Oslo, pp. 49-57

Jakubas D, Iliszko L, Wojczulanis-Jakubas K, Stempniewicz L (2012) Foraging by little auks in the distant marginal sea ice zone during the chick-rearing period. Polar Biol 35:73-81

Jakubas D, Trudnowska E, Wojczulanis-Jakubas K, Iliszko L, Kidawa D, Darecki M, Błachowiak-Samołyk K, Stempniewicz L (2013) Foraging closer to the colony leads to faster growth in little auks. Mar Ecol Prog Ser 489:263-278

Jakubas D, Wojczulanis-Jakubas K, Iliszko L, Darecki M, Stempniewicz L (2014) Foraging strategy of the little auk Alle alle throughout breeding season - switch from unimodal to bimodal pattern. J Avian Biol 45:551-560

Joiris CR (2011) A major feeding ground for cetaceans and seabirds in the South-Western Greenland Sea. Polar Biol 34:1597-1607

Kidawa D, Jakubas D, Wojczulanis-Jakubas K, Stempniewicz L, Trudnowska E, Boehnke R, Keslinka-Nawrot L, Błachowiak-Samołyk K (2015) Parental efforts of an Arctic seabird, the little auk Alle alle, under variable foraging conditions. Mar Biol Res 4:349-360

Kohler J, James TD, Murray T, Nuth C, Brandt O, Barrand NE, Aas HF, Luckman A (2007) Acceleration in thinning rate on western Svalbard glaciers. Geophys Res Lett 34. doi:10.1029/2007GL030681 (L18502)

Kotzerka J, Garthe S, Hatch SA (2010) GPS tracking devices reveal foraging strategies of black-legged kittiwakes. J Ornithol 151:459-467

Kovacs KM, Lydersen C, Overland JE, Moore SE (2011) Impacts of changing sea-ice conditions on Arctic marine mammals. Mar Biodivers 41:181-194

Krafft BA, Kovacs KM, Andersen M, Aars J, Lydersen C (2006) Abundance of ringed seals (Pusa hispida) in the fjords of Spitsbergen, Svalbard, during the peak molting period. Mar Mamm Sci 22:394-412

Kuletz KJ, Stephensen SW, Irons DB, Labunski EA, Brenneman KM (2003) Changes in distribution and abundance of Kittlitz's Murrelets Brachyramphus brevirostris relative to glacial recession in Prince William sound, Alaska. Mar Ornithol 31:133-140

Laidre KL, Stirling I, Lowry LF, Wiig Ø, Heide-Jørgensen MP, Ferguson SH (2008) Quantifying the sensitivity of Arctic marine mammals to climate-induced habitat change. Ecol Appl 18:97-125

Laidre KL, Stern H, Kovacs KM, Lowry L, Moore SE, Regehr EV, Ferguson SH, Wiig Ø, Boveng P, Angliss RP, Born EW, Litovka D, Quakenbush L, Lydersen C, Vongraven D, Ugarte F (2015) Arctic marine mammal population status, sea ice habitat loss, and conservation recommendations for the twenty-first century. Conserv Biol 29:724-737

Lydersen C, Assmy P, Falk-Petersen S, Kohler J, Kovacs KM, Reigstad M, Steen H, Strøm H, Sundfjord A, Varpe Ø, Walczowski W, Węsławski JM, Zajaczkowski M (2014) The importance of tidewater glaciers for marine mammals and seabirds in Svalbard, Norway. J Marine Syst 129:452-471

Mehlum F, Gabrielsen GW (1993) The diet of high-arctic seabirds in coastal and icecovered, pelagic areas near the Svalbard archipelago. Polar Res 12:1-20

Moe B, Stempniewicz L, Jakubas D, Angelier F, Chastel O, Dinessen F, Gabrielsen GW, Hanssen F, Karnovsky N, Rønning B, Welcker J, Wojczulanis-Jakubas K, Bech C (2009) Climate change and phenological responses of two seabird species breeding in the high-Arctic. Mar Ecol Prog Ser 393:235-246

Moore SE, Huntington HP (2008) Arctic marine mammals and climate change: impacts and resilience. Ecol Appl 12:157-165

Post E, Bhatt US, Bitz CM, Brodie JF, Fulton TL, Hebblewhite M, Kerby J, Kutz SJ, Stirling I, Walker DA (2013) Ecological consequences of sea-ice decline. Science 341:519-524

Prop J, Aars J, Bårdsen BJ, Hanssen SA, Bech C, Bourgeon S, de Fouw J, Gabrielsen GW, Lang J, Noreen E, Oudman T, Sittler B, Stempniewicz L, Tombre I, Wolters E, Moe B (2015) Climate change and the increasing impact of polar bears on bird populations. Front Ecol Evol 25. doi:10.3389/fevo.2015.00033

Schoen SK, Kissling ML, Hatch NR, Shanley CS, Stephensen SW, Jansen JK, Catterson NT, Oehlers SA (2013) Marine birds of Yakutat Bay, Alaska: evaluating summer distribution, abundance, and threats at sea. Mar Ornithol 41:55-61

Simberloff D, Dayan T (1991) The guild concept and the structure of ecological communities. Annu Rev Ecol Syst 22:115-143

Stempniewicz L, Błachowiak-Samołyk K, Węsławski JM (2007) Impact of climate change on zooplankton communities, seabird populations and arctic terrestrial ecosystem-a scenario. Deep-Sea Res II 54:2934-2945 
Stempniewicz L, Darecki M, Trudnowska E, Błachowiak-Samołyk K, Boehnke R, Jakubas D, Keslinka-Nawrot L, Kidawa D, Sagan S, Wojczulanis-Jakubas K (2013) Visual prey availability and distribution of foraging little auks (Alle alle) in the shelf waters of West Spitsbergen. Polar Biol 36:949-955

Sydeman WJ, Thompson SA, Kitaysky A (2012) Seabirds and climate change: roadmap for the future. Mar Ecol Progr Ser 454:107-117. doi:10.3354/meps09806

Tasker ML, Jones PH, Dixon T, Blake BF (1984) Counting seabirds at sea from ships: a review of methods employed and a suggestion for a standardized approach. Auk 101:567-577

van der Veen CJ (2004) Tidewater calving. J Glaciol 42:375-386

Vogedes D, Eiane K, Båtnes AS, Berge J (2014) Variability in Calanus spp. abundance on fine- to mesoscales in an Arctic fjord: implications for little auk feeding. Mar Biol Res 10:437-448

Węsławski JM, Legeżyńska J (1998) Glacier induced zooplankton mortality? J Plankton Res 20:1233-1240

Węsławski JM, Kwaśniewski S, Stempniewicz L, Błachowiak- Samołyk K (2006) Biodiversity and energy transfer to top trophic levels in two contrasting Arctic fjords. Pol Polar Res 27:259-278

Węsławski JM, Kwaśniewski S, Stempniewicz L (2009) Warming in the Arctic may result in the negative effects of increased biodiversity. Polarforschung 78:105-108

Wojczulanis-Jakubas K, Jakubas D, Stempniewicz L (2008) Avifauna of Hornsund area, SW Spitsbergen: present state and recent changes. Pol Polar Res 29:187-197 